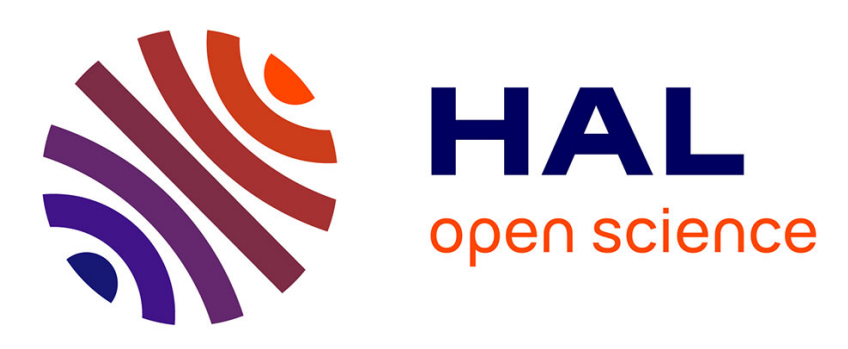

\title{
Alkali polyphosphates as new potential materials for thermal energy storage
}

Doan Pham Minh, Abdoul Razac Sane, Nawal Semlal, Patrick Sharrock, Ange Nzihou

\section{- To cite this version:}

Doan Pham Minh, Abdoul Razac Sane, Nawal Semlal, Patrick Sharrock, Ange Nzihou. Alkali polyphosphates as new potential materials for thermal energy storage. Solar Energy, 2017, 157, p.277-283. 10.1016/j.solener.2017.08.030 . hal-01630901

\section{HAL Id: hal-01630901 https://imt-mines-albi.hal.science/hal-01630901}

Submitted on 20 Oct 2018

HAL is a multi-disciplinary open access archive for the deposit and dissemination of scientific research documents, whether they are published or not. The documents may come from teaching and research institutions in France or abroad, or from public or private research centers.
L'archive ouverte pluridisciplinaire HAL, est destinée au dépôt et à la diffusion de documents scientifiques de niveau recherche, publiés ou non, émanant des établissements d'enseignement et de recherche français ou étrangers, des laboratoires publics ou privés. 


\title{
Alkali polyphosphates as new potential materials for thermal energy storage
}

\author{
Doan Pham Minh ${ }^{\mathrm{a}, *}$, Abdoul Razac Sane ${ }^{\mathrm{a}}$, Nawal Semlal ${ }^{\mathrm{b}}$, Patrick Sharrock ${ }^{\mathrm{a}}$, Ange Nzihou ${ }^{\mathrm{a}}$ \\ a Université de Toulouse, Mines Albi, CNRS, Centre RAPSODEE, Campus Jarlard, F-81013 Albi Cedex 09, France \\ b Direction R\&D, OCP SA, BP 118, 24000 El Jadida, Morocco
}

\section{A B S T R A C T}

Until now, molten salts (nitrate-based salts) are the main materials for sensible heat storage at industrial scale. The working temperature range of these materials is limited below $500{ }^{\circ} \mathrm{C}$. There is not yet a solution for sensible heat storage at high temperature. This paper aimed to investigate alkali polyphosphates $\left(\left(\mathrm{MPO}_{3}\right)_{\mathrm{n}}\right.$, with $\mathrm{M}=\mathrm{Li}$, $\mathrm{Na}$ or $\mathrm{K}$ ) as new promising materials for sensible heat storage at high temperature. Alkali polyphosphates could be formed by dehydration of monoalkali dihydrogenphosphates $\left(\mathrm{MH}_{2} \mathrm{PO}_{4}\right.$, with $\mathrm{M}=\mathrm{Li}$, Na or $\left.\mathrm{K}\right)$, which occurs below $400{ }^{\circ} \mathrm{C}$. Alkali polyphosphates resulted from this dehydration melted at 628,657 and $812{ }^{\circ} \mathrm{C}$ for sodium, lithium and potassium polyphosphate, respectively. All these liquids evaporated above $900{ }^{\circ} \mathrm{C}$ but no destruction of their chemical structure was recorded. Sodium polyphosphate seemed to be the most promising material for sensible heat storage at high temperature because of its large potential working temperature $\left(628-900{ }^{\circ} \mathrm{C}\right)$, its availability and its low cost compared to lithium and potassium polyphosphates. The results open new prospects for the development of the thermal energy storage field.

\section{Keywords:}

Alkali polyphosphate

Sensible heat storage

Thermal energy storage

\section{Introduction}

Energy consumption constantly increases worldwide. This is observed for all types of primary energy including coal, oil, natural gas, nuclear energy, hydroelectricity, and renewable energy. Fossil fuel (coal, oil and natural gas) still remains the world's dominant energy. However, the reserve of fossil fuel is limited with irregular distribution over the world. In addition, the consumption of fossil fuel leads to the emission of carbon dioxide in the atmosphere. Carbon dioxide is the main greenhouse gas (GHG) to cause global warming. Global warming causes serious problems to ecosystems, animal and humans: melting of glaciers leading to the rise in sea level, irregular weather patterns, massive crop failure, animal extinction, frequent wildfires... (Anderson et al., 2016; Arora et al., 2016; Punzón et al., 2016). So, the development of renewable energy is highly recommended for the $21^{\text {st }}$ century and is part of the global strategy for limiting the emission of GHG. The most common renewable energies include solar, biomass, wind, geothermal power or hydropower. Among them, solar energy has the highest potential with the development of photovoltaic (PV) and concentrated solar power (CSP) systems. Nevertheless, solar energy presents also various limits which relate to the intermittence of sunlight, the seasonal character, the irregular distribution between different countries and the dephasing between energy production and consumption. For CSP systems, the development of efficient thermal energy storage (TES) technology is a decisive factor to overcome the limits mentioned above.

TES is generally classified into 3 categories: sensible heat storage, latent heat storage, and thermochemical energy storage (Veerakumar and Sreekumar, 2016; Weinstein et al., 2015). Sensible heat storage consists in the heating of storage media without chemical reaction or phase change. Latent heat includes a phase change which allows a higher energy storage density compared to sensible heat storage. Thermochemical energy storage is based on a reversible reaction with endothermal and exothermal phases. Up-to-date, only sensible heat storage is developed at large industrial scale, and has a high growth rate recently. According to the International Energy Agency (IEA) (2014a), the cumulative CSP capacity worldwide reached around 0.5, 1.6 and $3.9 \mathrm{GW}$ in 2009, 2012 and 2014, respectively. IEA studies also predicted, in their BLUE Map scenario, that in 2050, CSP plants would provide $5 \%$ of the annual global electricity production (compared to $6 \%$ by solar PV), which shows the potential and interest in solar energy (IEA, 2010, 2014b).

Different materials can be used as media for sensible heat storage. They can be either liquid or solid during the charging and discharging phases. Liquid materials include mineral oil, synthetic oil, silicone oil, liquid sodium, carbonate salts, nitrate and nitrite salts (Gil et al., 2010). The most common commercial liquid material is known as Solar Salt containing $60 \mathrm{wt} \% \mathrm{NaNO}_{3}$ and $40 \mathrm{wt} \% \mathrm{KNO}_{3}$ (Fernández and Grageda, 2015; Peiró et al., 2016). It is currently used in different CSP plants such as ANDASOL (Dintera and Gonzalez, 2014; Solar Millenium AG, 2008;

\footnotetext{
Corresponding author.

E-mail address: doan.phamminh@mines-albi.fr (D. Pham Minh).
} 
Table 1

List of chemicals used in this work.

\begin{tabular}{lll}
\hline Name & Chemical formula & Supplier \\
\hline Sodium trimetaphosphate & $\mathrm{Na}_{3} \mathrm{P}_{3} \mathrm{O}_{9}$ & Aldrich \\
Sodium dihydrogenphosphate dihydrate & $\mathrm{NaH}_{2} \mathrm{PO}_{4} \cdot 2 \mathrm{H}_{2} \mathrm{O}$ & Aldrich \\
Lithium dihydrogenphosphate & $\mathrm{LiH}_{2} \mathrm{PO}_{4}$ & Aldrich \\
Potassium dihydrogenphosphate & $\mathrm{KH}_{2} \mathrm{PO}_{4}$ & Aldrich \\
\hline
\end{tabular}

Trabelsi et al., 2016), or GEMASOLAR (Rellosoa and García, 2015). Nitrate salts including Solar Salt have several advantages: (i) they are in liquid state at atmospheric pressure (and high temperature), which facilitates their use in CSP plants as TES material or heat transfer fluid (HTF); (ii) they have a working temperature range $\left(282-386{ }^{\circ} \mathrm{C}\right.$ for ANDASOL plants (Dintera and Gonzalez, 2014; Trabelsi et al., 2016) which allows generating vapor for steam turbine; (iii) they are less toxic than organic oils (Fernández and Grageda, 2015). In addition, they have low viscosity and low vapor pressure. However, nitrate salts have also various disadvantages and drawbacks. Their operational temperature is limited at $500{ }^{\circ} \mathrm{C}$ to avoid thermal decomposition of nitrate salts (Bauer et al., 2012). They are also used as fertilizer so its massive utilization in CSP plants can affect and compete with agricultural activities. When they are used as TES material, nitrate salts of high quality are recommended to avoid corrosion of tank and other equipment, which usually increases cost of CSP plant (Kuravi et al., 2013). Thus, numerous works have recently been devoted to the improvement of Solar Salt or the development of new materials for sensible heat energy storage (Fernandez et al., 2010; Fernández and Grageda, 2015; Gil et al., 2010; John et al., 2013; Kuravi et al., 2013; Martins et al., 2015).

This work focused on the development of several alkali polyphosphates $\left(\left(\mathrm{MPO}_{3}\right)_{\mathrm{n}}\right)$, with $\mathrm{M}=\mathrm{Na}, \mathrm{K}$, or $\left.\mathrm{Li}\right)$ as liquid media for sensible heat storage. In the literature, much work was reported on the investigation of nitrate salts, halogenated salts, carbonate salts, sulfates salts, metals and metal oxides (Hoshi et al., 2005). However, to the best our knowledge, there is no work reported yet on liquid (poly)phosphate-based products as TES materials. (Poly)phosphate-based products constitute a large family of inorganic salts with interesting physico- chemical and thermal properties, in particularly their low corrosion and high thermal stability compared to other inorganic salts.

\section{Materials and methods}

Table 1 summaries the chemicals used in this work. They were all provided by Aldrich, with high purity for R \& D purpose. All these chemicals were in fine powder form. They were used as received without further modification.

TG-DTA analysis was performed with a TA Instruments SDTQ600 analyzer with the heating rate of $5{ }^{\circ} \mathrm{Cmin}^{-1}$ under air flux $\left(100 \mathrm{~mL} \mathrm{~min}^{-1}\right)$. Platinum crucibles of $3 \mathrm{~mm}$ of diameter and $3 \mathrm{~mm}$ of height were used. For each analysis, around exactly 10-15 mg of solid was needed. In general, the instrument used can measure masse change and heat flow of the analysis (W/g). However, it was only used as TGDTA analyzer in this work. In fact, heating alkali phosphates $\left(\mathrm{MH}_{2} \mathrm{PO}_{4}\right.$ with $\mathrm{M}=\mathrm{Li}, \mathrm{Na}$, or $\mathrm{K}$ ) leads to the formation of alkali polyphosphates $\left(\left(\mathrm{MPO}_{3}\right)_{\mathrm{n}}\right)$ as shown thereafter in the Results section. When alkali polyphosphate melts, it exists in liquid state which can affect the weight signal. In addition, liquid polyphosphate could overflow the platinum crucible and then stick it on the microbalance of the TG-DTA apparatus. In this case, the microbalance has to be changed. To solve this problem, fine alumina powder was set on the surface of the microbalance to avoid the direct contact of the platinum crucible with the microbalance. Thus, the platinum crucible could be easily removed after TG-DTA test, despite eventual overflow of alkali polyphosphates. But the presence of alumina power disturbs the heat change signal. Thus, only DTA curves could be obtained, instead of DSC curves.

FTIR spectra were recorded with a Shimadzu FTIR $8400 \mathrm{~S}$ spectrometer, using a sensitive pyroelectric detector with a l-alanine-doped deuterated triglycine sulfate (DLATGS) element (maximum resolution of $0.85 \mathrm{~cm}^{-1}$, signal-to-noise ratio of 20,000: 1). The measurement was carried out directly with solid sample under powder form. Solid recovered from TG-DTA analysis was quickly analyzed by FTIR without further preparation.
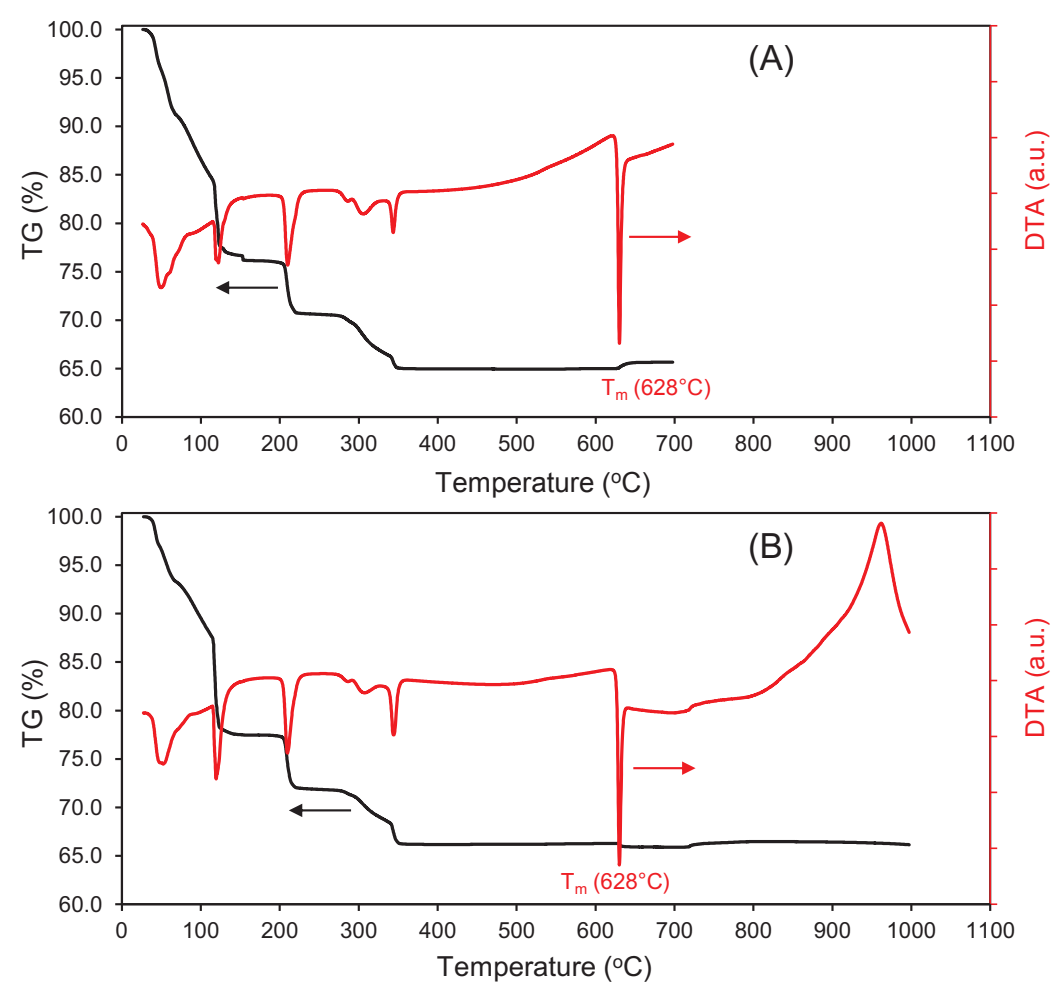

Fig. 1. TG-DTA under air atmosphere with the heating rate of $5{ }^{\circ} \mathrm{C} \mathrm{min}-1$ of $\mathrm{NaH}_{2} \mathrm{PO}_{4} \cdot 2 \mathrm{H}_{2} \mathrm{O}$ up to $700{ }^{\circ} \mathrm{C}$ (A) and $1000{ }^{\circ} \mathrm{C}$ (B). 


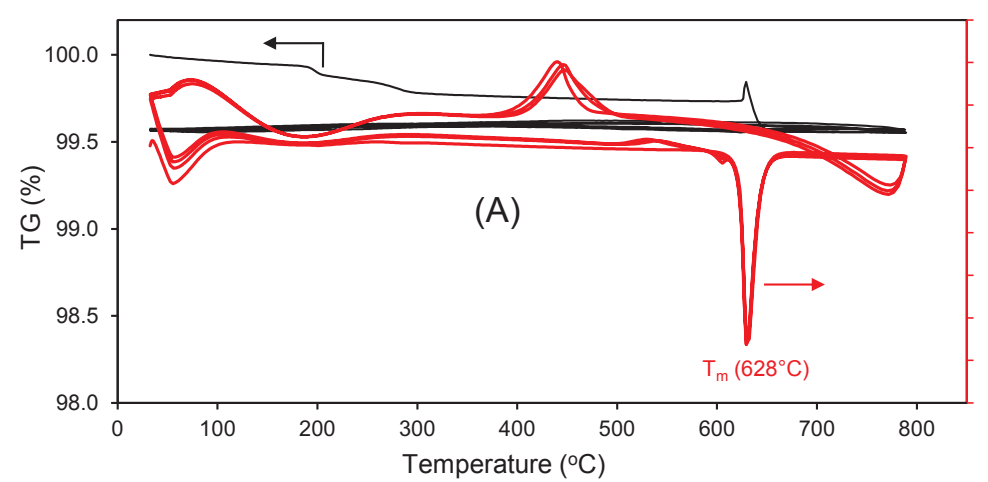

Fig. 2. TG-DTA cycle analysis under air atmosphere with the heating rate of $5{ }^{\circ} \mathrm{C} \mathrm{min}^{-1}$ of: (A and B) $\mathrm{Na}_{3} \mathrm{P}_{3} \mathrm{O}_{9}$; (C and D) $\mathrm{NaH}_{2} \mathrm{PO}_{4} \cdot 2 \mathrm{H}_{2} \mathrm{O}$.
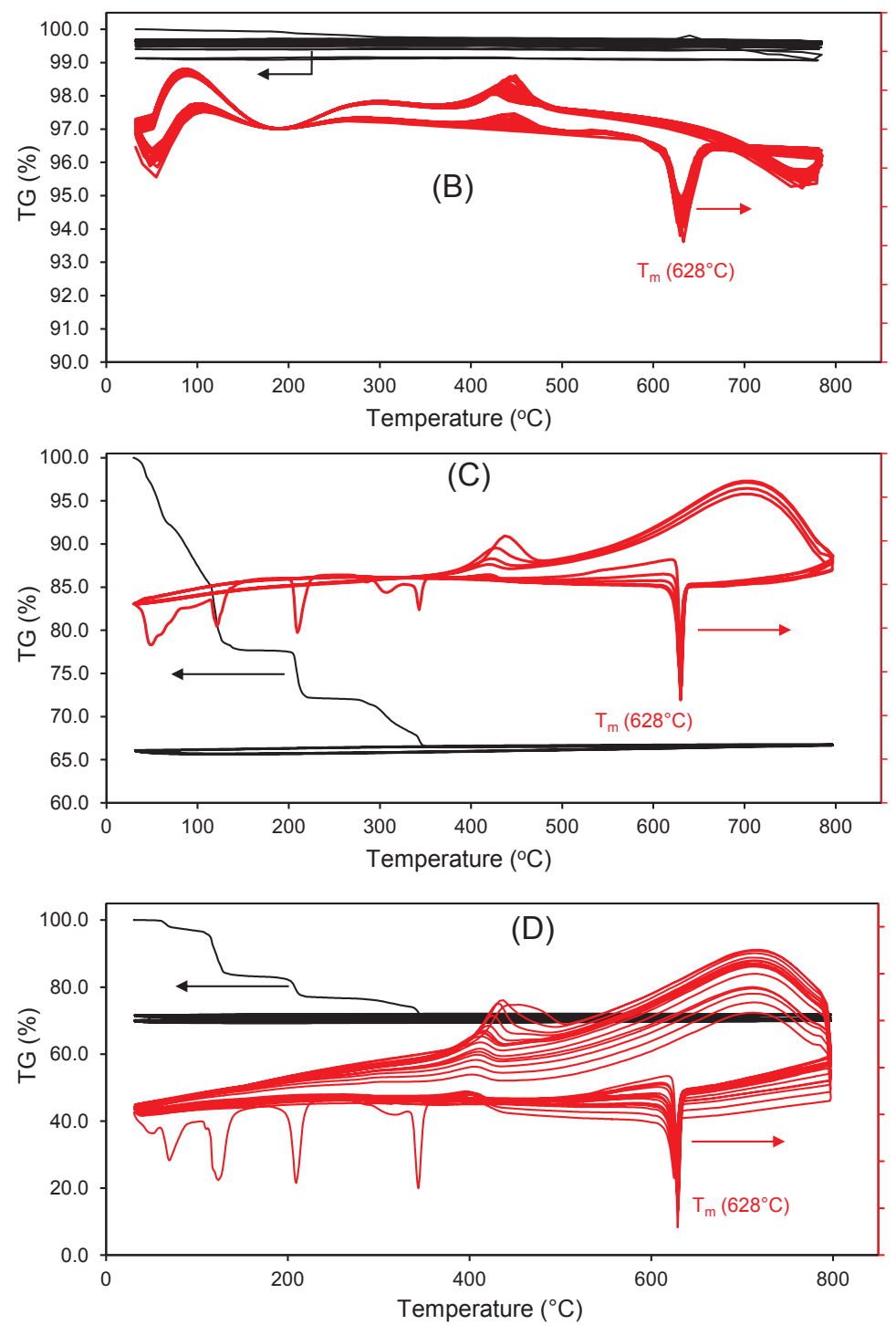

\section{Results}

\subsection{Characterization of sodium polyphosphate, $\left(\mathrm{NaPO}_{3}\right)_{n}$}

Fig. 1 shows TG-DTA curved of $\mathrm{NaH}_{2} \mathrm{PO}_{4} \cdot 2 \mathrm{H}_{2} \mathrm{O}$ under air flux in the temperature range of $30-700{ }^{\circ} \mathrm{C}(\mathrm{A})$ or $30-1000{ }^{\circ} \mathrm{C}(\mathrm{B})$.

This compound decomposed by dehydrations as follows:

$\mathrm{NaH}_{2} \mathrm{PO}_{4} \cdot 2 \mathrm{H}_{2} \mathrm{O} \rightarrow \mathrm{NaH}_{2} \mathrm{PO}_{4} \cdot \mathrm{H}_{2} \mathrm{O}+\mathrm{H}_{2} \mathrm{O}$

$\mathrm{NaH}_{2} \mathrm{PO}_{4} \cdot \mathrm{H}_{2} \mathrm{O} \rightarrow \mathrm{NaH}_{2} \mathrm{PO}_{4}+\mathrm{H}_{2} \mathrm{O}$
$\mathrm{NaH}_{2} \mathrm{PO}_{4} \rightarrow \mathrm{NaPO}_{3} \cdot 1 / 2 \mathrm{H}_{2} \mathrm{O}+1 / 2 \mathrm{H}_{2} \mathrm{O}$

$\mathrm{NaPO}_{3} \cdot 1 / 2 \mathrm{H}_{2} \mathrm{O} \rightarrow \mathrm{NaPO}_{3}+1 / 2 \mathrm{H}_{2} \mathrm{O}$

The first two weight losses took place at the temperature range of $30-145^{\circ} \mathrm{C}$, and corresponded to the dehydration of crystalized water. The last two weight losses were due to the condensation of dihydrogenophosphate anions $\left(\mathrm{H}_{2} \mathrm{PO}_{4}{ }^{-}\right)$, which happened in the temperature range of $190-350^{\circ} \mathrm{C}$. For each weight loss, the value recorded by TG-DTA apparatus was close to the theoretical value calculated for this compound $(11.5 \mathrm{wt} \%$ for the first two weight losses, and $5.8 \mathrm{wt} \%$ for the last two weight losses). Sodium polyphosphate, $\left(\mathrm{NaPO}_{3}\right)_{\mathrm{n}}$, was 

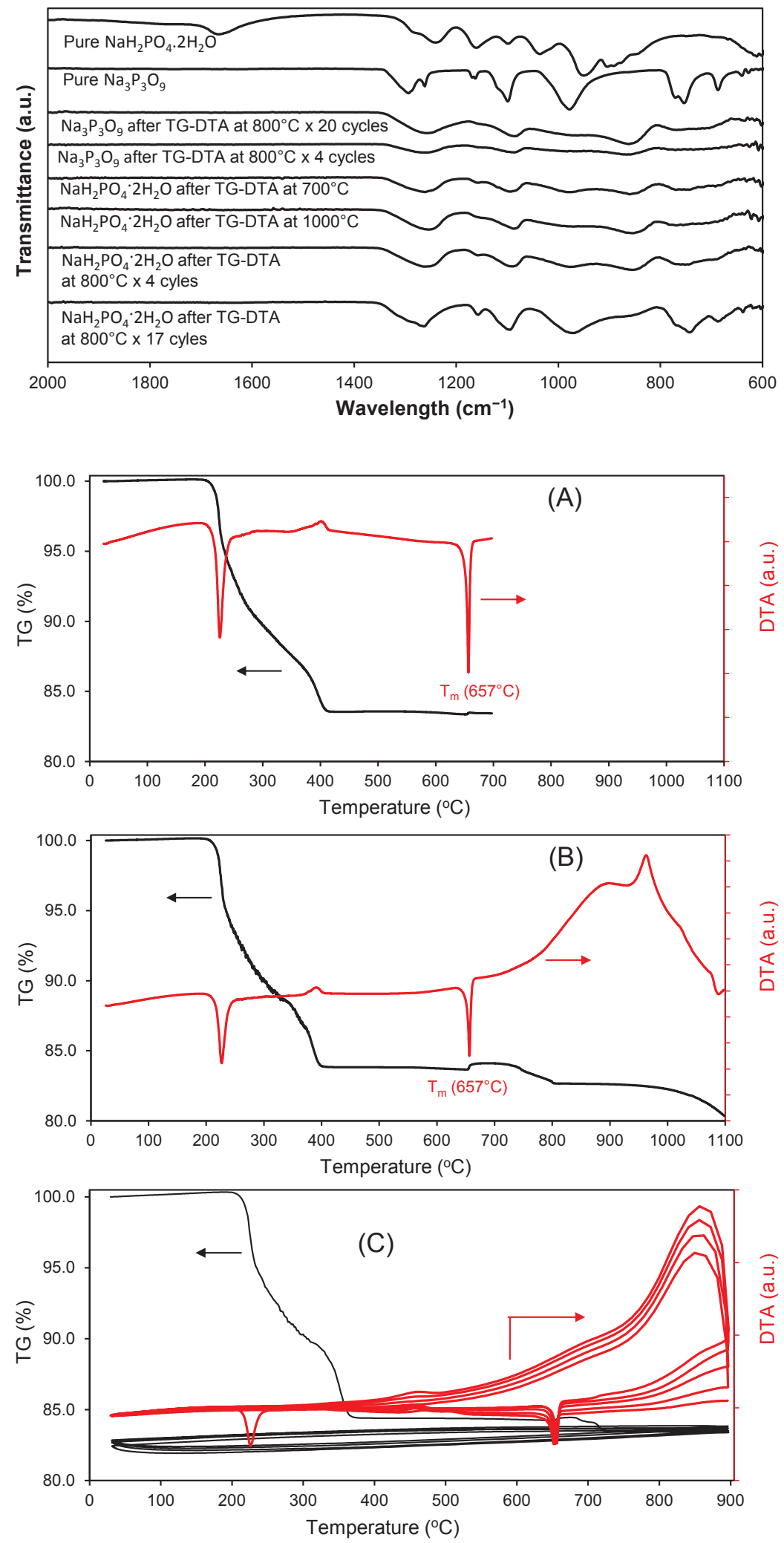

Fig. 3. FTIR spectra of $\mathrm{Na}_{3} \mathrm{P}_{3} \mathrm{O}_{9}$ and $\mathrm{NaH}_{2} \mathrm{PO}_{4} \cdot 2 \mathrm{H}_{2} \mathrm{O}$ before and after TGDTA analysis.

Fig. 4. TG-DTA of $\mathrm{LiH}_{2} \mathrm{PO}_{4}$ under air atmosphere with the heating rate of $5{ }^{\circ} \mathrm{C} \min ^{-1}$. expected as the product of the condensation. This product was thermally stable below $628^{\circ} \mathrm{C}$ without notable weight loss. Then, it melted to give the DTA peak at $628{ }^{\circ} \mathrm{C}$. This phenomenon slightly disturbed the signal of the microbalance of TG measurement. Finally, sodium polyphosphate seemed to evaporate above $900{ }^{\circ} \mathrm{C}$ (Fig. 1(B)). In the temperature of $628-900{ }^{\circ} \mathrm{C}$, no weight loss was observed. TG-DTA was repeated several times to confirm the repeatability of the analysis. The similarity of TG and DTA curves of Fig. 1(A) and (B) illustrates this repeatability.

Fig. 2 shows TG-DTA curves of $\mathrm{Na}_{3} \mathrm{P}_{3} \mathrm{O}_{9}$ and $\mathrm{NaH}_{2} \mathrm{PO}_{4} \cdot 2 \mathrm{H}_{2} \mathrm{O}$ with 4 , 17 or 20 consecutive heating-cooling cycles in the temperature range of 30-800 ${ }^{\circ} \mathrm{C}$. For $\mathrm{Na}_{3} \mathrm{P}_{3} \mathrm{O}_{9}$ (Fig. 2(A) and (B)), the first heating step led to some small weight losses $(<0.5 \mathrm{wt} \%)$ and the melting at $628^{\circ} \mathrm{C}$. For the next cooling and heating steps, there was no notable weight loss 

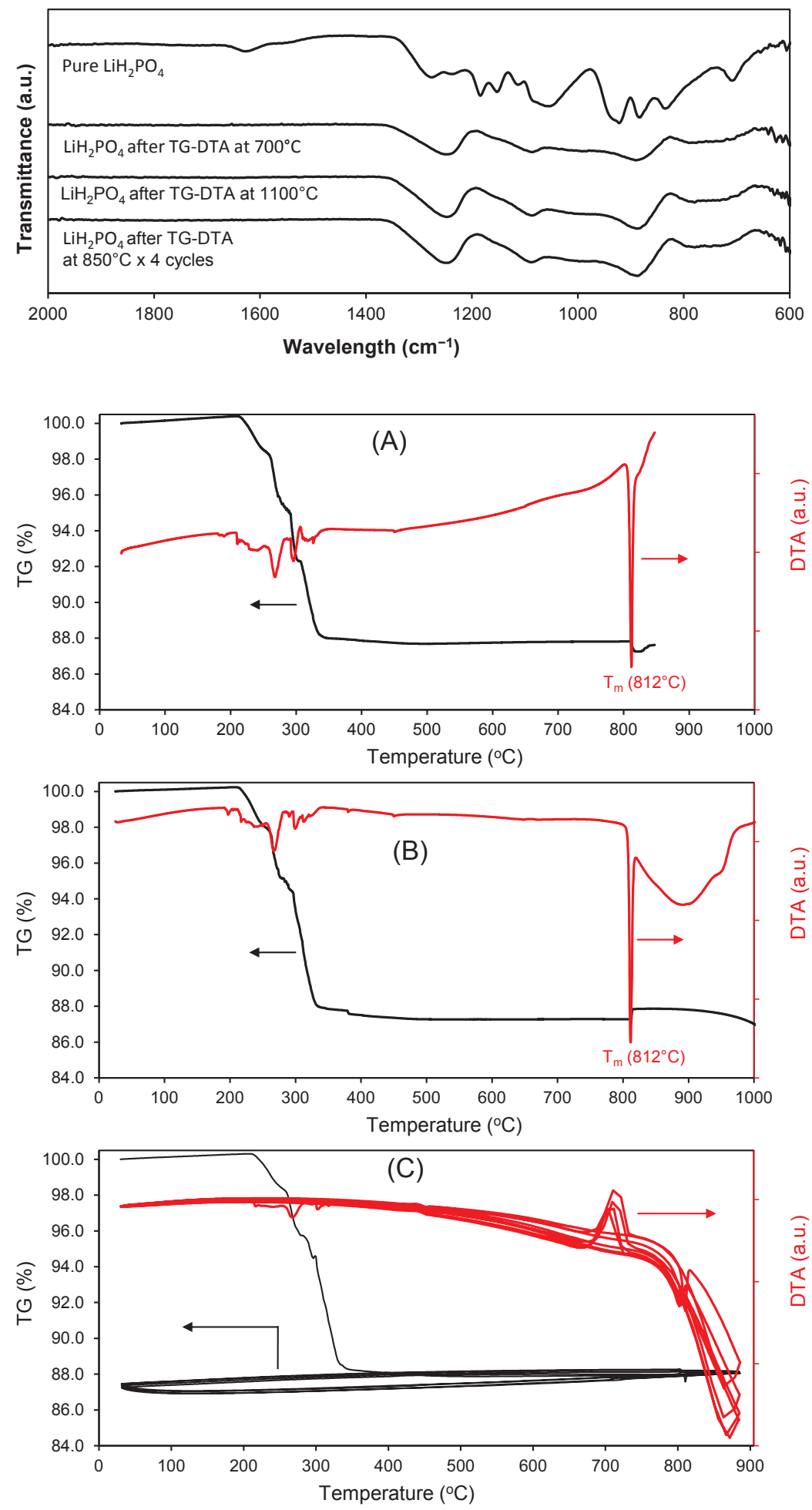

Fig. 5. FTIR spectra of synthesized $\mathrm{LiPO}_{3}$ before and after TG-DTA analysis.

Fig. 6. TG-DTA of $\mathrm{KH}_{2} \mathrm{PO}_{4}$ under air atmosphere with the heating rate of $5{ }^{\circ} \mathrm{C} \mathrm{min}^{-1}$. which demonstrated the thermal stability of the resulting product, $\left(\mathrm{NaPO}_{3}\right)_{\mathrm{n}}$, within the temperature range studied. The results were repeated for both the analyses with 4 and 20 consecutive heating-cooling cycles. Further FTIR analysis shows that no significant change was observed inside its structure (Fig. 3). For $\mathrm{NaH}_{2} \mathrm{PO}_{4} \cdot 2 \mathrm{H}_{2} \mathrm{O}$ (Fig. 2 (C) and (D)), the first heating step led to different dehydrations as mentioned previously, as well as the melting at $628^{\circ} \mathrm{C}$. Then, $\left(\mathrm{NaPO}_{3}\right)_{\mathrm{n}}$ formed from this step was thermally stable during 4 or 17 heating-cooling cycles.

Fig. 3 shows FTIR spectra of $\mathrm{Na}_{3} \mathrm{P}_{3} \mathrm{O}_{9}$ and $\mathrm{NaH}_{2} \mathrm{PO}_{4} \cdot 2 \mathrm{H}_{2} \mathrm{O}$ before and after TG-DTA analyses. As mentioned above, the heating of $\mathrm{Na}_{3} \mathrm{P}_{3} \mathrm{O}_{9}$ and $\mathrm{NaH}_{2} \mathrm{PO}_{4} \cdot 2 \mathrm{H}_{2} \mathrm{O}$ above $628^{\circ} \mathrm{C}$ led to the melting of these salts and the formation of sodium polyphosphate, $\left(\mathrm{NaPO}_{3}\right)_{\mathrm{n}}$. The structure of $\left(\mathrm{NaPO}_{3}\right)_{\mathrm{n}}$ seemed to be similar after being heated to different temperatures of 700,800 or $1000{ }^{\circ} \mathrm{C}$. In fact, FTIR analysis shows that all the solids recovered from TG-DTA analysis had similar spectra. FTIR analysis illustrated also the structural change of $\mathrm{Na}_{3} \mathrm{P}_{3} \mathrm{O}_{9}$ to more stable form $\left(\left(\mathrm{NaPO}_{3}\right)_{\mathrm{n}}\right)$ after melting at $628^{\circ} \mathrm{C}$, due to the oligomerization or polymerization of $\mathrm{NaPO}_{3}$ unit. 


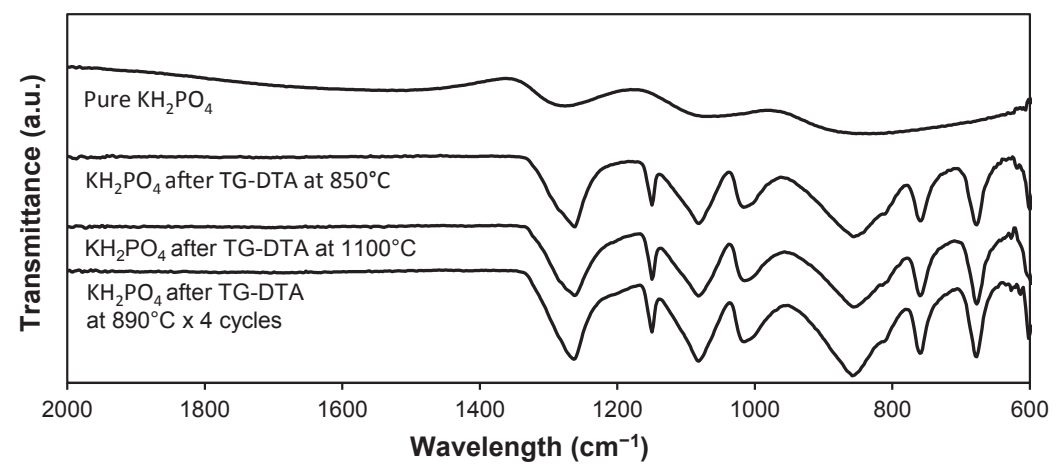

Fig. 7. FTIR spectra of synthesized $\mathrm{KPO}_{3}$ before and after TG-DTA analysis.

\subsection{Characterization of lithium polyphosphate, $\left(\mathrm{LiPO}_{3}\right)_{n}$}

Fig. 4 shows TG-DTA analysis of $\mathrm{LiH}_{2} \mathrm{PO}_{4}$ under air atmosphere. $\mathrm{LiH}_{2} \mathrm{PO}_{4}$ had a progressive dehydration in the temperature range of $200-415^{\circ} \mathrm{C}$ (at the heating rate of $5{ }^{\circ} \mathrm{C} \min ^{-1}$ ). The maximum of DTA signal of this dehydration was found at $225.5^{\circ} \mathrm{C}$. The weight loss of this dehydration was recorded around $17 \mathrm{wt} \%$, which corresponds to the following equation:

$\mathrm{LiH}_{2} \mathrm{PO}_{4} \rightarrow \mathrm{LiPO}_{3}+\mathrm{H}_{2} \mathrm{O}$

$\mathrm{LiPO}_{3}$ resulting from this dehydration melted at $657{ }^{\circ} \mathrm{C}$. As previously observed with $\mathrm{NaPO}_{3}$, this melting caused a perturbation of TG signal. At liquid state, $\mathrm{LiPO}_{3}$ was thermally stable up to around $900{ }^{\circ} \mathrm{C}$ before its evaporation, as observed in Fig. 4(B). Thus, consecutive heating-cooling cycles was then performed with $\mathrm{LiH}_{2} \mathrm{PO}_{4}$ in the temperature range of $30-900{ }^{\circ} \mathrm{C}$ (Fig. $4(\mathrm{C})$ ). Any notable weight loss was observed after the first heating step. Also, the maximum of DTA peak was constant at $657{ }^{\circ} \mathrm{C}$ indicating that there was probably no structural change of $\mathrm{LiPO}_{3}$ after its formation by the first melting at $657{ }^{\circ} \mathrm{C}$.

Fig. 5 shows FTIR spectra of the initial $\mathrm{LiH}_{2} \mathrm{PO}_{4}$ powder and the solids recovered from TG-DTA analysis. $\mathrm{LiH}_{2} \mathrm{PO}_{4}$ had several peaks at $1300-700 \mathrm{~cm}^{-1}$, which must be due to $\mathrm{P}-\mathrm{O}$ vibrations. For the solids recovered from TG-DTA analyses, all the spectra were similar to each other, and did not depend on the final temperature of TG-DTA analysis. In particular, as observed previously, TG-DTA analysis at $30-1100{ }^{\circ} \mathrm{C}$ showed the partial evaporation of $\left(\mathrm{LiPO}_{3}\right)_{\mathrm{n}}$ above $900{ }^{\circ} \mathrm{C}$. We suppose that this evaporation did not cause any notable change in the structure of the remaining solid because its FTIR spectrum was also similar to those of the solids treated at lower temperatures.

\subsection{Characterization of potassium polyphosphate, $\left(\mathrm{KPO}_{3}\right)_{n}$}

TG-DTA analysis of $\mathrm{KH}_{2} \mathrm{PO}_{4}$ is presented in Fig. 6. The dehydration of this compound took place in the temperature range of $210-350{ }^{\circ} \mathrm{C}$. This dehydration seemed to happen in several consecutive steps as indicated by the presence of multiple DTA peaks. The global weight loss at $210-350{ }^{\circ} \mathrm{C}$ reached approximatively $13 \mathrm{wt} \%$ and corresponded to the following equation:

$\mathrm{KH}_{2} \mathrm{PO}_{4} \rightarrow \mathrm{KPO}_{3}+\mathrm{H}_{2} \mathrm{O}$

Thus, $\mathrm{KPO}_{3}$ was formed above $350{ }^{\circ} \mathrm{C}$. This compound did not show any notable change up to $812{ }^{\circ} \mathrm{C}$, where it melted. The disturbance of the melting step on TG signal was again observed. Liquid $\mathrm{KPO}_{3}$ was thermally stable up to around $900{ }^{\circ} \mathrm{C}$. Then, it evaporated above $900{ }^{\circ} \mathrm{C}$ as observed in Fig. 6 (B).

Fig. 6 (C) shows heating-cooling cycles of $\mathrm{KH}_{2} \mathrm{PO}_{4}$. The dehydration of $\mathrm{KH}_{2} \mathrm{PO}_{4}$ was again confirmed during the first heating step. When $\mathrm{KPO}_{3}$ was formed, it remained thermally stable during repeated heating-cooling cycles.

Fig. 7 presents FTIR spectra of the initial $\mathrm{KH}_{2} \mathrm{PO}_{4}$ and the solids recovered after TG-DTA analyses. For $\mathrm{KH}_{2} \mathrm{PO}_{4}$, peaks of $\mathrm{P}-\mathrm{O}$ vibration were also observed at the wavelength of around $1300-700 \mathrm{~cm}^{-1}$. For the solids recovered from TG-DTA analyses, their FTIR spectra were similar to each other, indicating the structural similarity of these melted solids. In other words, the formation of the same potassium polyphosphate, $\left(\mathrm{KPO}_{3}\right)_{\mathrm{n}}$, was expected after its melting point at $812{ }^{\circ} \mathrm{C}$ and its structure was stable even above its evaporation temperature.

For a conventional CSP system using molten salt as TES material, the working temperature required is limited between around $281-386^{\circ} \mathrm{C}$, as previously mentioned. These nitrate-based salts are upto-date the main commercial products for sensible heat storage. There is no available solution for TES at higher temperatures yet. Current research is focused on the development of refractory concretes and ceramics as new TES materials (Fernandez et al., 2010; Fernández and Grageda, 2015; Gil et al., 2010; John et al., 2013; Kuravi et al., 2013; Martins et al., 2015). However, these materials still need improvements mostly concerning their low thermal conductivity, their difficulty for shaping, or their high cost. So, this work demonstrated that liquid alkali polyphosphates could be an interesting solution for sensible heat storage at high temperatures. Among three monoalkali polyphosphates studied, sodium polyphosphate $\left(\left(\mathrm{NaPO}_{3}\right)_{\mathrm{n}}\right)$ seemed to be the most interesting product. It melts at $628^{\circ} \mathrm{C}$ and could be stable up to around $900{ }^{\circ} \mathrm{C}$. The melting point of lithium polyphosphate $\left(\left(\mathrm{LiPO}_{3}\right)_{\mathrm{n}}\right)$ is close to that of sodium polyphosphate and this compound is also stable up to around $900{ }^{\circ} \mathrm{C}$. But in general, lithium compounds are less available and more expensive than sodium compounds. As for potassium polyphosphate $\left(\left(\mathrm{KPO}_{3}\right)_{\mathrm{n}}\right)$, it melts at $812{ }^{\circ} \mathrm{C}$ and evaporates above $900{ }^{\circ} \mathrm{C}$. So this compound seems to be not convenient for sensible heat storage because of the narrow temperature range wherein it is stable in liquid state.

\section{Conclusions}

For the first time, alkali polyphosphates were investigated as liquid media for sensible heat storage at high temperature. Alkali polyphosphates $\left(\left(\mathrm{MPO}_{3}\right)_{\mathrm{n}}\right.$, with $\mathrm{M}=\mathrm{Li}$, Na or $\left.\mathrm{K}\right)$ could be easily obtained from the dehydration of the corresponding monoalkali dihydrogenphosphate $\left(\mathrm{MH}_{2} \mathrm{PO}_{4}, \mathrm{M}=\mathrm{Li}, \mathrm{Na}, \mathrm{K}\right)$. After their melting point, alkali polyphosphates were thermally stable up to around $900{ }^{\circ} \mathrm{C}$. Above $900{ }^{\circ} \mathrm{C}$, alkali polyphosphates evaporated, but no chemical decomposition took place. Sodium polyphosphate was the most promising product thanks to its large temperature range in the liquid state $\left(628-900{ }^{\circ} \mathrm{C}\right)$, its availability and its low cost compared to lithium or potassium poly phosphates.

Further work should determine physico-chemical properties for these alkali polyphosphates in liquid state such as heat capacity, thermal conductivity, density, viscosity, corrosive property etc. These data would allow the design of a new solution for sensible heat storage at high temperature.

\section{Acknowledgment}

The authors would like to acknowledge the financial support from Prayon and OCP S.A Group, and ANRT (Association Nationale de la 
Recherche et de la Technologie, France). The authors gratefully thank colleagues at the RAPSODEE research center, CNRS UMR 5302, for technical help.

\section{References}

Anderson, T.R., Hawkins, E., Jones, P.D., 2016. $\mathrm{CO}_{2}$, the greenhouse effect and global warming: from the pioneering work of Arrhenius and Callendar to today's earth system models. Endeavour 40 (3), 178-187.

Arora, A., Rao, S.A., Chattopadhyay, R., Goswami, T., George, G., Sabeerali, C.T., 2016. Role of Indian Ocean SST variability on the recent global warming hiatus. Glob. Planet. Change 143, 21-30.

Bauer, T., Breidenbach, N., Pfleger, N., Laing, D., 2012. Overview of molten salt storage systems and material development for solar thermal power plants. In: Presented at the 2012 National Solar Conference (SOLAR 2012), Denver CO.

Dintera, F., Gonzalez, D.M., 2014. Operability, reliability and economic benefits of CSP with thermal energy storage: first year of operation of ANDASOL 3. Energy Proc. 49, 2472-2481.

Fernandez, A.I., Martiez, M., Segarra, M., Martorell, I., Cabeza, L.F., 2010. Selection of materials with potential in sensible thermal energy storage. Solar Energy. Mater. Solar Cells 94, 1723-1729.

Fernández, U.A.G., Grageda, M., 2015. 3 - Using molten salts and other liquid sensible storage media in thermal energy storage (TES) systems. In: Advances in Thermal Energy Storage Systems. Woodhead Publishing, pp. 49-63.

Gil, A., Medrano, M., Martorell, I., Lazaro, A., Dolado, P., Zalba, B., Cabeza, L.F., 2010. State of the art on high temperature thermal energy storage for power generation. Part 1 - Concepts, materials and modellization. Renew. Sustain. Energy Rev. 14, $31-55$.

Hoshi, A., Mills, D.R., Bittar, A., Saitoh, T.S., 2005. Screening of high melting point phase change materials (PCM) in solar thermal concentrating technology based on CLFR. Solar Energy 79, 332-339.
IAE, 2010. International Energy Agency, Technology roadmap_Concentrating solar power, Paris, France.

IAE, 2014a. < http://www.iea.org/publications/freepublications/publication/ technologyroadmapsolarthermalelectricity_2014edition.pdf > (accessed on July 07, 2017).

IAE, 2014b. International Energy Agency, Technology roadmap_Solar photovoltaic energy, Paris, France.

John, E., Hale, M., Selvam, P., 2013. Concrete as a thermal energy storage medium for thermocline solar energy storage systems. Solar Energy 96, 194-204.

Kuravi, S., Trahan, J., Goswami, D.Y., Rahman, M.M., Stefanakos, E.K., 2013. Thermal energy storage technologies and systems for concentrating solar power plants. Prog. Energy Combust. Sci. 39, 285-319.

Martins, M., Villalobos, U., Delclos, T., Armstrong, P., Bergan, P.G., Calvet, N., 2015. New concentrating solar power facility for testing high temperature concrete thermal energy storage. Energy Proc. 75, 2144-2149.

Peiró, G., Gasia, J., Miró, L., Prieto, C., Cabeza, L.F., 2016. Experimental analysis of charging and discharging processes, with parallel and counter flow arrangements, in a molten salts high temperature pilot plant scale setup. Appl. Energy 178, 394-403.

Punzón, A., Serranoa, A., Sánchez, F., Velasco, F., Preciado, I., González-Irusta, J.M., López-López, L., 2016. Response of a temperate demersal fish community to global warming. J. Marine Syst. 161, 1-10.

Rellosoa, S., García, E., 2015. Tower technology cost reduction approach after Gemasolar experience. Energy Proc. 69, 1660-1666.

Solar Millenium AG, 2008. The Parabolic Trough Power Plants Andasol 1 to 3. www. solarmillennium.de (accessed on July 07, 2017).

Trabelsi, S.D., Chargui, R., Qoaider, L., Liqreina, A., Guizani, A.A., 2016. Techno-economic performance of concentrating solar power plants under the climatic conditions of the southern region of Tunisia. Energy Convers. Manage. 119, 203-214.

Veerakumar, C., Sreekumar, A., 2016. Phase change material based cold thermal energy storage: Materials, techniques and applications - a review. Inter. J. Refrig. 67, 271-289.

Weinstein, L.A., Loomis, J., Bhatia, B., Bierman, D.M., Wang, E.N., Chen, G., 2015. Concentrating solar power. Chem. Rev. 115, 12797-12838. 